\title{
Wrecks as artificial lobster habitats in the German Bight
}

\author{
Roland Krone • Alexander Schröder
}

Received: 27 September 2009/Revised: 10 March 2010/Accepted: 16 March 2010/Published online: 7 April 2010

(C) Springer-Verlag and AWI 2010

\begin{abstract}
Once, the European lobster could be found in high abundances on rocky substrate around the island of Helgoland. Since the 1960s, the stock has been decreasing dramatically. Until now, it has been assumed that the lobster stock of Helgoland is the only one in the German Bight. Here, we provide first information about lobster distribution inside the German Bight off Helgoland. Diving in situ observations revealed that lobsters inhabit at least $15.6 \%$ of all 64 investigated wrecks. Considering the difficulties of detecting lobsters at wrecks, the true percentage is most likely much higher. Their locations are spatially homogenously distributed throughout the inspected area. The study indicates a broad distribution of the European lobster over the German Bight. The habitats provided by a considerable fraction of the more than one thousand wrecks outside the Wadden Sea are potential lobster refuges within the mud and sand dominated sea floor. Besides providing additional habitats, they represent stepping stones enhancing the connectivity of the North Sea lobster population.
\end{abstract}

Keywords Homarus gammarus · Wrecks · Artificial structures · North Sea $\cdot$ German Bight

\section{Introduction}

The European lobster, Homarus gammarus (L.), is a large, highly mobile decapod crustacean of considerable

Communicated by H.-D. Franke.

R. Krone $(\varangle) \cdot$ A. Schröder

Section Functional Ecology, Alfred Wegener Institute

for Polar and Marine Research, Am Handelshafen 12,

27570 Bremerhaven, Germany

e-mail: Roland.krone@awi.de commercial importance within the north-east Atlantic and the Mediterranean. European lobsters usually inhabit irregularly shaped rocky substrates and boulder fieldsrare bottom types and thus a limiting factor within the sand- and mud-dominated south-eastern North Sea. The assumed rareness of lobsters in the German Bight outside Helgoland is generally attributed to the perceived scarcity of suitable habitats. However, many irregularly shaped artificial hard-substrate structures can be found within the German Bight. More than 1,500 wrecks (ships, airplanes, containers, etc.) have been registered by German authorities (BSH 2009), but so far no investigation of their ecological function has been performed.

The European lobster Homarus gammarus is the largest decapod crustacean of the southern North Sea, reaching a total length of $60 \mathrm{~cm}$ and an age of 60 years (Phillips 2006). This omnivorous top predator is widely distributed throughout European seas-from the east Mediterranean, along the Atlantic coast around the British Isles to northern Norway. It does not, however, inhabit the Baltic Sea. $H$. gammarus can be found from the intertidal down to a water depth of $60 \mathrm{~m}$ (Galparsoro et al. 2009) and inhabits fully marine waters as well as low saline coastal waters of only 10 PSU (Linnane et al. 2000). Clawed lobsters live solitarily within crevices between rocks or inside holes which they shape between hard substrate and soft bottom. Unlike the similar American lobster (H. americanus), which occurs at the east coast of North America at water depths down to $200 \mathrm{~m}, \mathrm{H}$. gammarus does not dig own burrows into pure soft bottom. Therefore, its population size depends on the availability of appropriate hard-substrate biotopes suitable for settling. Within the investigation area, up to 26,000 larvae are released annually between May and August by each adult female. The pelagic larval phase lasts up to 4 weeks until the larval stage 4 finally sinks to the sea 
floor in search for a suitable habitat for settlement (Phillips 2006; Schmalenbach 2009).

Up to now, only a small subpopulation was recognised in the German Bight in the vicinity of the rocky island of Helgoland (Schmalenbach and Buchholz 2010; Ulrich et al. 2001). Like most of all North Atlantic and Mediterranean subpopulations it was decimated drastically in the mid1900s (Browne et al. 2001; Cobb and Castro 2006; Franke and Gutow 2004). During the 1930s, the annual catch from Helgoland reached up to 87,000 lobsters. Today only a few hundred specimens are caught here yearly. Several anthropogenic factors might be the cause of the decline, e.g. overexploitation and pollution of the sea through chemicals (Schmalenbach et al. 2009). Within German waters, the European lobster today is considered a highly endangered species (Rachor et al. 1998).

Neighbouring populations are found at the rocky coasts of Norway (Agnalt et al. 2006; Jørstad et al. 2004), Great Britain (Smith et al. 1998; Jensen et al. 1994) and around the Oosterschelde in the Netherlands (Ulrich et al. 2001). Investigations of Ulrich et al. (2001) suggest that the lobster population of Helgoland is widely separated from those found in other parts of the North Sea. However, more extensive studies by Triantafyllidis et al. (2005) found the North Sea lobster stocks of Germany, southern Norway, East England, and Scotland to be part of one single large population. Only the lobsters of the enclosed Oosterschelde (The Netherlands) and of North Norway were well separated from the North Sea population by mitochondrial DNA comparison. If these sampled lobster groups belong to one population, there must be some genetic exchange between the spatially separated subpopulations.

Adult lobsters have been observed to reside in the same place over several years, but in principle, H. gammarus can cover large distances in search, for e.g. food or shelter, at least when there are suitable habitats along the way (Hepper 1978). However, the known lobster habitats of the east coast of England, the Oosterschelde, Helgoland, and the south Norwegian coast are separated by very large distances with only sandy bottom. During their pelagic phase, lobster larvae can cover some distance drifting with the anticlockwise residual current in the North Sea. Nevertheless, they need to find an adequate habitat at metamorphosis, when their benthic live begins. The scarcity of natural reefs providing suitable lobster habitats led to the assumption of separated populations and little is known about their connectivity.

So far, no scientific investigations have been undertaken about the existence of lobsters in the German Bight outside Helgoland. The only evidence that existing came from occasional bycatches in crab-pots (H. D. Franke and I. Schmalenbach, pers. comm.) and anecdotic observations by professional divers at offshore constructions (A. Stutz, pers. comm.).

However, numerous wrecks in the German Bight provide a lot of solid habitats, serving as a kind of secondary artificial reefs (sensu Pickering et al. (1998): structures not placed with the intention to serve as a reef), which could be assumed to be inhabited by European lobsters.

The aim of the present study was to investigate to which degree the numerous wrecks inside the German Bight are inhabited by $H$. gammarus, whether they can be counted as lobster habitats in the German Bight and what role they may play for the connectivity between the local North Sea lobster subpopulations.

\section{Methods}

Study area

The German Bight (Fig. 1) sea floor is dominated by loose sediments from coarse sands to mud in the deeper parts (Figge 1981), like most of the North Sea. The large intertidal flats of the Wadden Sea are separated from the open North Sea by chains of sandy barrier islands. Helgoland, inside the south-eastern German Bight, represents the only natural rocky shores between southern England and the southern Norway coast. Apart from this, natural hard substrates exist only at a few stony bolder reefs from glacial relicts, which are scattered on the Borkum Reef Ground and along the eastern side of the glacial Elbe valley.

Within the German Bight outside the national base line, salinity ranges from 35 offshore to 25 PSU close to the

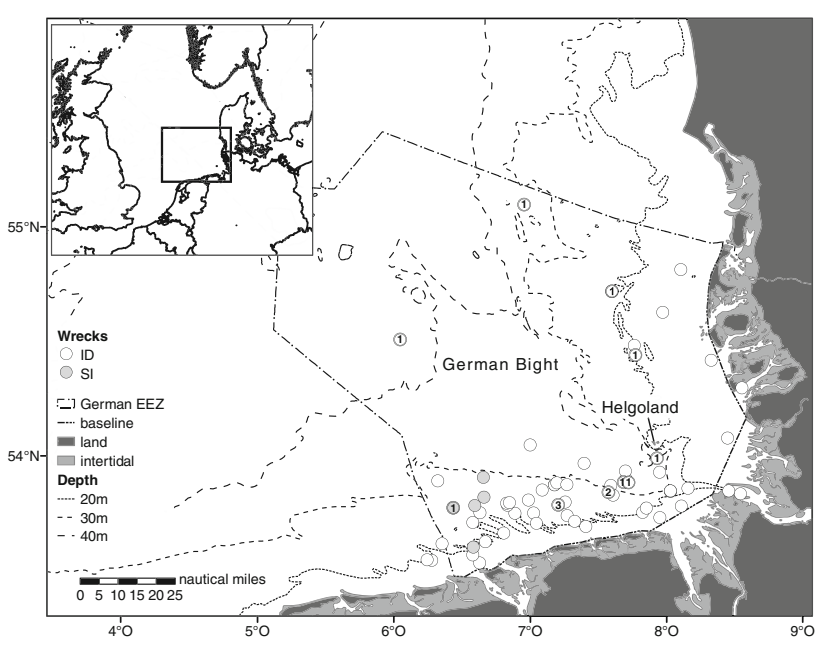

Fig. 1 Distribution of inspected wrecks in the German Bight. The number of lobster detections at wrecks are given by the numbers inside the dots. Wrecks scientifically investigated (SI) and wrecks investigated by inspection divers (ID) 
plume of the river Elbe (Jones and Howarth 1995). The maximum depth reaches $45 \mathrm{~m}$ in the north-west (compare Fig. 1), except for the small area of the Helgoland Trench, with a maximum of $60 \mathrm{~m}$. The underwater visibility strongly depends on the distance to the coast, the water depth, and the hydrodynamic conditions. They are ranging from only a few centimetres close to the cost or after storms to over $5 \mathrm{~m}$ in offshore locations and after the rare periods of calm weather.

\section{Wrecks}

Within German waters, more than 1,500 Wrecks are presently known to the authorities (BSH 2009), and new one keep being added. Most of them are ships, but also airplanes, containers, or other bodies are among them.

To assure safe shipping, the German federal maritime agency (BSH) keeps a record of all known wrecks in German waters. All wrecks which present possible hazards to navigation are inspected irregularly by divers to verify their position, depth, and condition. Since 2004, some of these control dives are recorded on video for safety and documentation reasons. The BSH kindly supplied video records of 59 different wrecks (from the years 2004 to 2008 , one visit per wreck) for our analysis. These wrecks are situated between 8.6 and $44.5 \mathrm{~m}$ (on average $27 \mathrm{~m}$ ) water depth and are 5-127 years old. The average surface area of the wrecks is $1,200 \mathrm{~m}^{2}\left( \pm \mathrm{SD} 1,800 \mathrm{~m}^{2}\right)$. Most of them are made of steel. Wrecks in deeper waters are visited rarely since they do not endanger ship traffic and diving becomes more difficult with increasing water depth (Fig. 1). From an ecological point of view, the order and position of the searched wrecks are rather random depending only on nautical requirements.

To gain a representative number of wreck visits within an adequate time and cost effort, we combined scientific wreck studies with an analysis of video footage taken during routine wreck inspections by the $\mathrm{BSH}$.

\section{Routine wreck inspections}

At each location, the BSH divers descend to the wreck and dives alongside it as far as the umbilical cable and maximum dive limits permit. During the dive, they search the deepest depression (scour) and try visiting as many parts of the wreck as possible, as well as locating the highest point. The diver is equipped with a continuously recording helmet camera (water proof housing, 1/4"-Sony-CCD-ColourChip, display and recorder inside the dive boat) and a helmet light. As these dives serve only for technical inspection, no ecological parameters are recorded, but underwater visibility, maximum water depth and length of time of the video are noted. The diver gains a broad overview of the wreck, which is recorded on video, allowing a later identification of the fauna on the wreck.

\section{Scientific dives}

We investigated five shipwrecks (Fig. 1) in detail applying scientific survey methods; wrecks were chosen in the vicinity of planned offshore wind farms for a comparison of artificial structures. On each wreck, the mobile mega fauna was recorded on 3-4 belt transects laid out into arbitrary directions from where the diver first hit the wreck. Each transect was $15 \mathrm{~m}$ long, $1 \mathrm{~m}$ wide and $1 \mathrm{~m}$ high. Transect width and height were controlled by 1-m spacers clipped to the transect line and a hand held $1 \mathrm{~m}$ ruler. Equipped with a $26 \mathrm{~W}$ halogen underwater torch, the diver moved slowly along the transect line and stopped at every marker to search the $1 \mathrm{~m}^{3}$ ahead for fish and mobile decapod crustaceans (Wilhelmsson et al. 2006). If a straight transect extended beyond the wreck area, the diver changed the direction at the edge of the wreck to complete the transect within the wreck area. The inside of the ship hull was not surveyed for safety reasons. The diver reported all organisms found within the transect via telephone to the recording person located in the dive boat. Here, we present the recorded detections of $H$. gammarus only. An analysis of the distribution of other species will be published elsewhere.

All dives were done at slack water between 6 am and $5 \mathrm{pm}$. For each wreck, the total extent and the percentage covered by the dive surveys were calculated.

This ratio was used to estimate the probability of detecting lobsters at any particular wreck. Possible coherence of the wreck system for moving lobster outside the Wadden Sea is displayed by plotting a $3 \mathrm{~nm}$ buffer around each wreck, representing a conservative estimate for adult lobster moving range (Hepper 1978; Jensen et al. 1994).

\section{Results}

This investigation includes many types of wreckages, e.g. large hulls, expanses of ruins, a lost anchor with its chain, a ship container, and a car. Most wrecks $(n=50)$, however, are ship ruins made of steel, although smaller wrecks occasionally consist of wood or plastic. The average projected wreck surface was $1,200 \mathrm{~m}^{2}$. The recorded visibility ranged from 0.4 to $5.5 \mathrm{~m}$ (average $1.75 \pm 1.3 \mathrm{~m} \mathrm{SD}$ ). The length of the video records varied from 2 to $36 \mathrm{~min}$ (average $11.6 \pm 6.6 \mathrm{~min} \mathrm{SD}$, total $690 \mathrm{~min}$ ). Considering video records length and the divers' speed and technique, on average $43 \%$ of the 64 wrecks' surface were searched. At 9 of the 59 wrecks on inspection videos, we found a total number of 12 lobsters (on average 33\% of the area of these lobster wrecks were inspected). At 7 wrecks, 
respectively, one individual was detected. At another single wreck, two and at one other three individuals were identified on single video recordings. At one of the five scientifically investigated wrecks, a single lobster was found. Considering all wreck investigations together, lobster were detected at $15.6 \%$ of all wrecks.

The highest wreck densities are found along the main traffic lanes in the German Bight south of Helgoland (Fig. 1). Accordingly, most of the investigated wrecks were located in these areas (Fig. 2). Out of the 54 wrecks inspected here, at six wrecks $(11.1 \%)$ lobsters were observed. In the northern part the density of wrecks is much lower and only few wrecks were inspected. At four of the ten inspected wrecks (36.4\%) in the north of Helgoland, lobsters were found-all of them in offshore locations deeper than $20 \mathrm{~m}$.

All of the specimens had an estimated carapax length of more than $6 \mathrm{~cm}$ (age $>3$ years). One lobster, found during a scientific dive mission, had a carapax length of approx. $14 \mathrm{~cm}$ (age $>8$ years). Sex was not identified. The occurrences of lobsters over the investigated wrecks are relatively homogenously distributed (Fig. 1) and exhibit no obvious pattern so far. Most lobsters were found at shipwrecks or expanses of ruins (projected expanse of $188-2,000 \mathrm{~m}^{2}$ ). One individual was detected at a single large steam boiler ( $4 \mathrm{~m}$ width $\times 9 \mathrm{~m}$ length) lying on the sand ground. Approximatly $90 \%$ of all wrecks presented here are located less than $3 \mathrm{~nm}$ from the next wreck (Fig. 2).

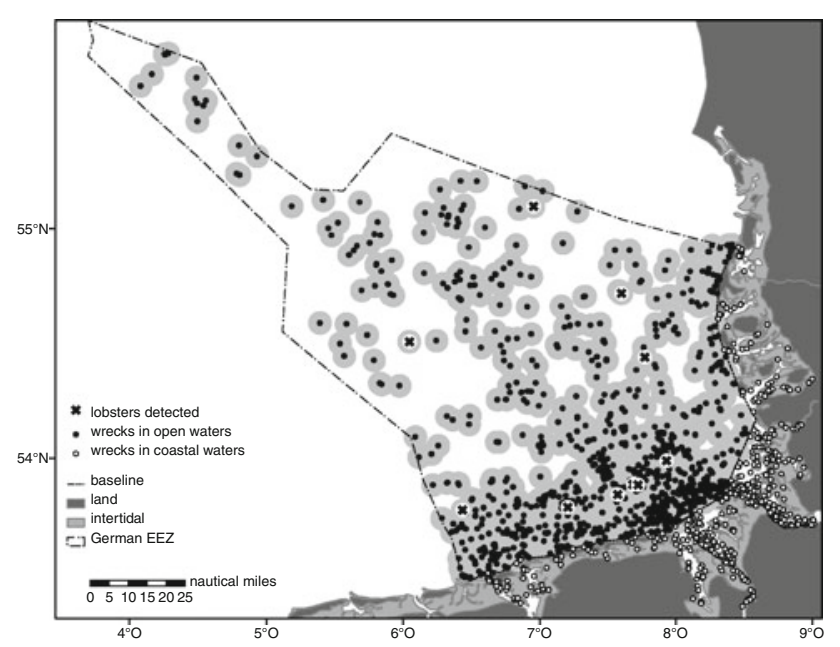

Fig. 2 Distribution of wrecks inside the German exclusive economic zone. Over 1,000 wrecks are found seawards of the baseline, another well over 500 in coastal waters. The greyish area represents a buffer of $3 \mathrm{~nm}$ around each wreck. In the inner German Bight more than $90 \%$ of all wrecks are well connected

\section{Discussion}

We used the method of non-ecological transect analysis, which did not reveal absolute abundances since search times and visibility varied strongly between the wreck visits, and small specimens were hardly detectable. However, the videos provide evidence of the occurrence of lobsters at a considerable percentage of the investigated wrecks. These occurrences can be considered as a minimum number and can be tentatively projected by carefully correcting the numbers by the effort. This shortcoming of the method may not allow for concise estimates of actual population size, but adds an enormous coverage of wrecks through the professional diver videos, which could not be investigated scientifically with the given time and money constrains. In addition to this, it provides the rare opportunity to study wrecks and their inhabitants at places were diving is extremely difficult (e.g. inside traffic zones).

The detected specimens were found in crevices as well as in relatively open spaces among solid wreck compartments. As reported by Langhamer et al. (2009) and Spanier (1994), we also found that lobsters tend to prefer places between solid structures and bottom that can be excavated. Since the BSH dives were not intended to compile data about the local fauna, we can assume that by far not all lobsters present at these wrecks were detected, particularly since these crustaceans often stay hiding during the day (Jensen et al. 1994). In fact, we assume that there is a substantially higher number of lobsters at more than the $15 \%$ of the observed wrecks. Considering the above-mentioned fractions of the wrecks that were actually inspected (33-43\% of their surface), and the fact that the inspection dives were not set up to detect lobsters, the real percentage of lobster-inhabited wrecks may be assumed to be two to three times higher. Assuming that the investigated wrecks are representative for most of the wrecks in the open German Bight, a similar percentage of the over 1,000 wrecks outside the baseline (Fig. 2) might be inhabited by lobsters. Within the baseline, the Wadden Sea and the estuaries represent habitats with considerably different physical conditions. However, as lobsters are reported to also inhabit coastal waters (Linnane et al. 2000), a certain percentage of these wrecks might also be considered as potential habitats and stepping stones.

Although at rocky shores and also at Helgoland lobsters are found up to the intertidal (Linnane et al. 2000), all lobsters were observed at wrecks in more than $20 \mathrm{~m}$ depth. The number of inspected wrecks in offshore locations north of Helgoland is rather low, but indeed four of the five inspected wrecks were inhabited by at least one lobster. This might indicate that in these offshore locations the percentage of lobster-inhabited wrecks is very high. 
Despite the high number of inspected wrecks in the southern German Bight, the frequency of wrecks with lobster detections was lower than that in the north. Whether this holds true when more wrecks are inspected in the north and what factors could be responsible for such an unequal distribution (e.g. the intensive ship traffic, hydrography) remains uncertain until more inspection data are available.

No lobsters were observed at the wrecks in shallower waters closer to the Wadden Sea. This could be related to various reasons. Methodical influences such as longer dive times at deeper locations (average record length $44.5 \mathrm{~min}$ at $>20 \mathrm{~m}$ depth vs. $31.1 \mathrm{~min}$ in shallower areas) could increase the chance of finding lobster through larger coverage of the wrecks. On the other hand, higher sediment loads in the more coastal water, hydrodynamics, a different wreck associated biocoenosis, or other environmental factors could be the responsible parameters determining the suitability of wrecks for lobsters. However, the relative low number of detected lobsters and the low number of inspected wrecks in the northern part of the German Bight precludes statistical analysis on ecological aspects. Nevertheless, the high frequencies of lobster observations are a strong argument in themselves. A higher number of wreck inspections in these areas expected for the coming years will alleviate this problem and allow more detailed analyses of factors determining whether a wreck is inhabited by lobsters or not.

Since lobsters prefer rocky habitats with suitable hideouts and are known to reside in one place over several years (Jensen et al. 1994; Bannister et al. 1994), and were never found in hundreds of German Bight beam trawl catches from pure soft bottom (own unpublished data), it is likely that the observed individuals are not just attracted temporarily from the adjacent muddy and sandy areas or from Helgoland but actually use the wrecks as their habitat.

Homarus gammarus are known to migrate over larger distances of more than $16.0 \mathrm{~nm}$ (Hepper 1978). However, it is unclear whether they also cover similar distances over open sandy bottom. From southern England, lobsters were reported to move on average $3.2 \mathrm{~nm}$ (males $2.6 \mathrm{~nm}$; females $3.7 \mathrm{~nm}$ ) from their release point at artificial reef amidst sandy grounds (Jensen et al. 1994). Most of all wrecks presented here, however, are located less than this distance from each other. Therefore, the individuals found at the wrecks could have reached the spots as migrating adults. The fact that also some wrecks located at greater distances from neighbouring wrecks are inhabited by lobsters (see Fig. 2) indicates that some larger distances can be overcome. Within the German Bight the population found around Helgoland may be the main source for emigrating lobsters and their larval instars. Nevertheless, it appears that a part of the lobsters-inhabited wrecks far from Helgoland shelter permanent inhabitants and thus contribute to the overall population in the eastern North Sea.
The large distances between the known occurrences of lobster subpopulations in the North Sea led to the assumption of effectively separated populations. In a conservative estimate, the distance covered by the drift of larvae zoea instar one and two during their predominant pelagic phase of 7 days (in German waters during summer temperature; Schmalenbach and Buchholz 2010; Tully and Ó Céidigh 1987) reaches approximately $33 \mathrm{~nm}$ (considering $0.2 \mathrm{~nm} \mathrm{~h}^{-1}$ effective residual current (Hickel 1972)). As this, as well as the distance covered by migrating adults (Jensen et al. 1994), is much smaller than the distance between the different recognised North Sea populations, a genetic exchange between them was considered very unlikely (Ulrich et al. 2001).

However, the distance between most wrecks is much smaller than the possible range of moving lobsters and drifting larvae. The observation that a considerable percentage of the wrecks in the German Bight seem to be inhabited by lobsters allows a different perspective on the availability of potential lobster habitats in this area perceived as largely barren sands. The assumed lack of suitable habitats between known lobster populations in the North Sea left scientists wonder how the apparent genetic similarity between them could be explained (Ulrich et al. 2001; Triantafyllidis et al. 2005). However, these sand and mud areas are actually interspersed by thousands of potential lobster habitats throughout the North Sea. The approximately 1,500 registered wrecks, spread across most of the open German Bight, may not only present permanent suitable habitats for lobsters, but probably also serve as stepping stones. Assuming a similar distribution of wrecks in the Dutch, British, Danish and Norwegian parts of the North Sea, these would effectively connect widely separated locations and permit a genetic exchange between the known hotspots of local European lobster subpopulations explaining their observed genetic similarity.

Acknowledgments We would like to thank the German Federal Maritime Agency (BSH, Bundesamt für Seeschifffahrt und Hydrographie), namely H. Pietrek (wreck data), R. Wehlisch, M. Sulanke and T. Stahl (wreck divers) and the ship command of the vessel Wega for supporting us with wreck information and the underwater video material. Special thanks go to the captain R. Voss and the crew of the vessel FS Heincke for supporting the scientific dive missions. G. Dederer, P. Krämer and T. Alpermann joined our scientific dive team. We thank the scientific diving centre of the AWI and L. Gutow for logistical support and A. Sorensen for stylistics.

\section{References}

Agnalt AL, Kristiansen TS, Jørstad KE (2006) Growth, reproductive cycle, and movement of berried European lobsters (Homarus gammarus) in local stock off southwestern Norway. ICES J Mar Sci 64:288-297 
Bannister RCA, Addison JT, Lovewell SRJ (1994) Growth, movement, recapture rate and survival of hatchery-reared lobsters (Homarus gammarus (Linnaeus, 1758)) released into the wild on the English east coast. Crustaceana 67:156-172

Browne RM, Mercer JP, Duncan MJ (2001) An historical overview of the Republic of Ireland's lobster (Homarus gammarus Linnaeus) fishery, with references to European and Northern American (Homarus americanus Milne Edwards) lobster landings. Hydrobiologia 465:49-62

BSH (2009) http://www.bsh.de/de/Meeresdaten/Seevermessung_und_ Wracksuche/Wracksuche/index.jsp

Cobb JS, Castro KM (2006) Homarus species. In: Phillips B (ed) Lobster: biology, management, aquaculture, and fisheries. Blackwell, Oxford, pp 310-339

Figge K (1981) Sedimentverteilung in der Deutschen Bucht. 1:250,000.; Dt. Hydrogr. Inst., Hamburg. Karte Nr. 2900

Franke HD, Gutow L (2004) Long-term changes in the macrozoobenthos around the rocky island of Helgoland (German Bight, North Sea). Helgol Mar Res 58:3003-3310

Galparsoro I, Borja Á, Bald J, Liria P, Chust G (2009) Predicting suitable habitat for the European lobster (Homarus gammarus), on the Basque continental shelf (Bay of Biscay), using ecological-niche factor analysis. Ecol Modell 220:556-567

Hepper BT (1978) Population dynamics of the lobster Homarus gammarus (L.) off the coasts of England. Fish Res Tech Rep 41

Hickel W (1972) Kurzzeitige Veränderungen hydrographischer Faktoren und der Sestonkomponenten in driftenden Wassermassen in der Helgoländer Bucht. Helgol Wiss Meeresunters 23:383-392

Jensen AC, Collins EKF, Free EK, Bannister RCA (1994) Lobster (Homarus gammarus) movement on an artificial ref: the potential use of artificial reefs for stock enhancement. Crustaceana 67:198-211

Jones JE, Howarth MJ (1995) Salinity models of the southern North Sea. Cont Shelf Res 15:705-727

Jørstad E, Prodöhl A, Agnalt AL, Hughes M, Apostolidis P, Triantafyllidis A, Farestveit E, Kristiansen TS, Mercer J, Svåsand T (2004) Sub-arctic populations of European lobster, Homarus gammarus, in northern Norway. Environ Biol Fish 69:223-231

Langhamer O, Wilhelmsson D, Engström J (2009) Artificial reef effect and fouling impacts on offshore wave power foundations and buoys-a pilot study. Estuar Coast Shelf Sci 82:426-432
Linnane A, Ball B, Munday B, Mercer JP (2000) On the occurrence of juvenile lobster Homarus gammarus in intertidal habitat. J Mar Biol Ass UK 80:375-376

Phillips BF (2006) Lobsters: biology, management, aquaculture and fisheries. Blackwell, Oxford

Pickering H, Whitmarsh D, Jensen A (1998) Artificial reefs as a tool to aid rehabilitation of coastal ecosystems: investigating the potential. Mar Pollut Bull 37:505-514

Rachor E, Bick A, Bönsch R, Gosselck F, Harms J, Heiber W, Kröncke I, Kube J, Michaelis H, Reise K, Schroeren V, van Bernem KH, Voss J (1998) Rote Liste der bodenlebenden wirbellosen Meerestiere. In: Binot M, Bless R, Boyes P, Gruttke H, Pretscher P (ed) Rote Liste gefährdeter Tiere Deutschlands. Schriftenreihe für Landschaftspflege und Naturschutz, Heft 55:290-300

Schmalenbach I (2009) Studies on the developmental conditions of the European lobster (Homarus gammarus Linnaeus, 1758) at the rocky island of Helgoland (German Bight, North Sea). Dissertation, University Hamburg

Schmalenbach I, Buchholz F (2010) Vertical positioning and swimming performance of lobster larvae (Homarus gammarus) in an artificial water column at Helgoland, North Sea. Mar Biol Res 6:89-99

Schmalenbach I, Buchholz F, Franke HD, Saborowski R (2009) Improvement of rearing conditions of juvenile lobsters (Homarus gammarus) by co-culturing with juvenile isopods (Idotea emarginata). Aquaculture 289:297-303

Smith IP, Collins KJ, Jensen AC (1998) Movement and activity patterns of the European lobster, Homarus gammarus, revealed electromagnetic telemetry. Mar Biol 132:611-623

Spanier E (1994) What are the characteristics of a good artificial reef for lobsters? Crustaceana 67:173-186

Triantafyllidis A, Apostolidis AP, Katsares V, Kelly E, Mercer J, Hughes M, Jørstad KE, Tsolou A, Hynes R, Tryantaphyllidis C (2005) Mitochondrial DNA variation in the European lobster (Homarus gammarus) throughout the range. Mar Biol 146:223-235

Tully O, Ó Céidigh P (1987) The seasonal and diel distribution of lobster larvae (Homarus gammarus) (Linnaeus) in the neuston of Galway Bay. J Cons Int Explor Mer 44:5-9

Ulrich I, Müller J, Schütt C, Buchholz F (2001) A study of population genetics in the European lobster, Homarus gammarus (Decapoda, Nephropdidae). Crustaceana 74:825-837

Wilhelmsson D, Malm T, Öhman M (2006) The influence of offshore wind power on demersal fish. ICES J Mar Sci 63:775-784 